\title{
Electricity Utility Companies Entering Private Sector Markets
}

\section{How to Avoid Distortions of Competition}

\author{
Andreas Abegg and Phil Baumann
}

\section{Contents}

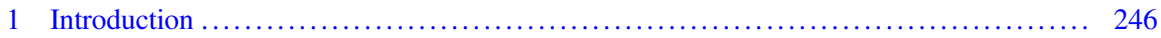

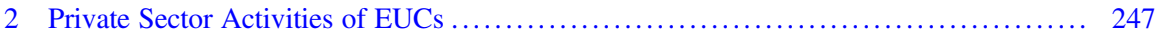

2.1 Distinction from Public Tasks of EUCs ............................... 247

2.2 Examples of Private Sector Services Provided by EUCs .................... 249

2.3 Why Do EUCs Become Active in the Private Sector? ...................... 251

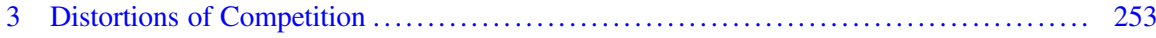

3.1 Financial Advantages ............................................ 253

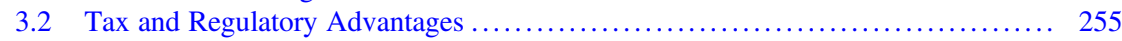

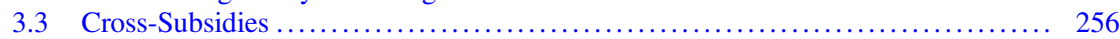

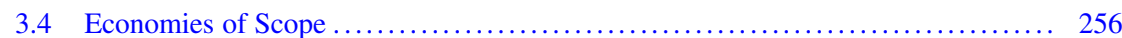

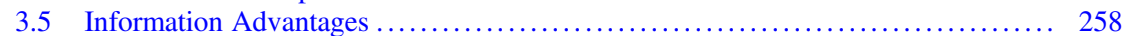

4 Legal Requirements for EUCs to Avoid Distortions of Competition .................. 259

4.1 Constitutional Requirements ...................................... 259

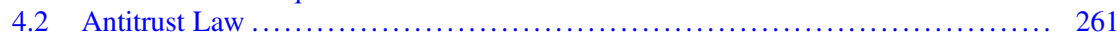

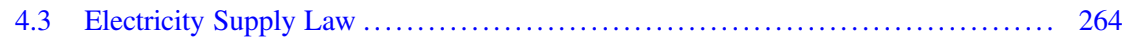

5 Measures to Avoid Distortions of Competition .............................. 266

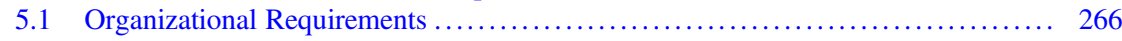

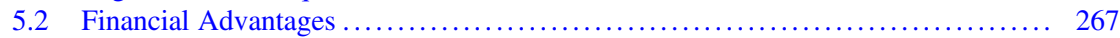

5.3 Tax and Regulatory Advantages ................................... 269

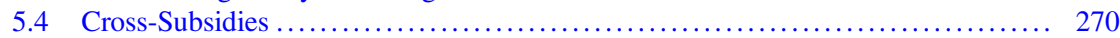

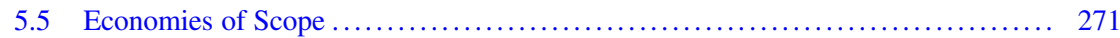

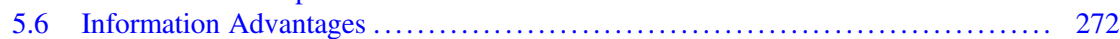

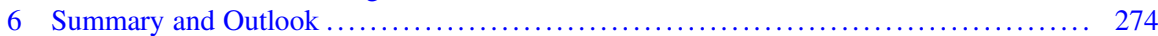

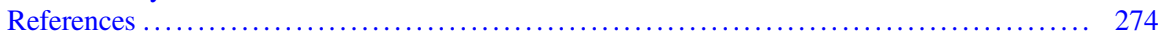

The chapter is based on previous findings published as Abegg and Baumann (2020).

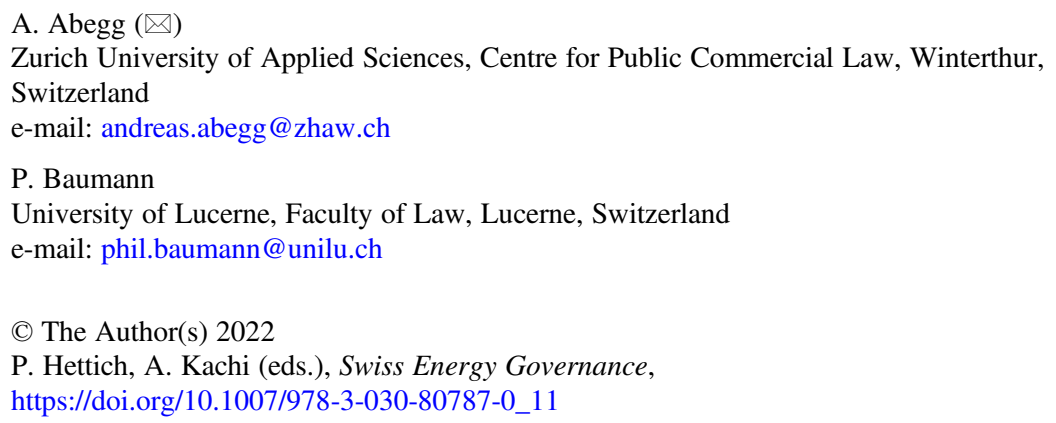




\begin{abstract}
On the one hand, energy utility companies (EUCs) fulfill public tasks assigned to them by the state. On the other hand, they are also often active as entrepreneurs in the free market. For example, they supply electricity products to major customers, install photovoltaic and e-mobility systems and provide services in the areas of building technology, metering and telecommunications. In such private sector activities, energy utility companies potentially enjoy unjustified advantages due to the fact that they are publicly controlled and perform public tasks: they receive particularly good financing conditions, are taxed on a privileged basis and benefit from economies of scope and information advantages when public and private sector tasks are carried out in parallel. Such privileges may distort competition or prevent companies from entering a market. This chapter examines the legal requirements for dealing with this issue and proposes specific measures with which legislators and authorities can avoid harmful effects of private sector activities by EUCs.
\end{abstract}

\title{
1 Introduction
}

In Switzerland, almost $90 \%$ of the electricity utility companies (EUCs) are public sector utilities and therefore belong to the state. ${ }^{1}$ In the course of the partial opening of the electricity market that has already taken place and the intended complete opening thereof, these public utilities are faced with the challenge of compensating for revenue losses from traditional "monopoly" areas. ${ }^{2}$ At the same time, energy supply companies are expected to make their contribution to increasing energy efficiency and expanding renewable energies within the framework of the federal Energy Strategy 2050. ${ }^{3}$

This is the backdrop against which EUCs are expanding their business activities by moving from their public service sectors into private markets and thus becoming hybrid operators. In Switzerland, state activity in the private sector is permitted in principle, in accordance with legal doctrine and case law. ${ }^{4}$ However, EUCs' increased activities in the private sector are regularly the subject of controversial public debate. ${ }^{5}$ The attention has been in particular on accusations of EUCs reaping unjustified competitive advantages and thus benefiting from an "unequal playing field" in competition with private providers.

\footnotetext{
${ }^{1}$ Swiss Federal Office of Energy (2018a), p. 1.

${ }^{2}$ See Graf and Waldmeier (2016), p. 12.

${ }^{3}$ See, e.g., Vettori et al. (2018), p. 4.

${ }^{4}$ BGE 138 I 378, E. 6.3.2 and 6.3.3. In particular, the Swiss Electricity Supply Act (Stromversorgungsgesetz) does not explicitly prohibit EUCs from carrying out certain private sector activities (Kratz 2018, p. 97).

${ }^{5}$ See for example Enz (2018), p. 1 et seq. and 11; Müller (2017), p. 19; Vonplon (2019), p. 13; see further Schneider (2016), p. 647 et seq.; see also the campaign "Fair ist anders!" of the Berne SME trade association, which is aimed in particular at BKW's private sector activities. Available at www. fair-ist-anders.ch.
} 
The issue of competition distortions arising from private sector activities is not limited to the corresponding entrepreneurial activities of EUCs; it is a problem that occurs generally when state activities press into the private sector. ${ }^{6}$ So far, however, a sector-specific analysis of the private sector activities of EUCs has not been conducted. In particular, it is unclear which private sector activities are being carried out by EUCs. In addition, the public discussion focuses on allegedly competitiondistorting behavior of a particular EUC, while there is a lack of comprehensive analysis of the whole field.

This chapter aims to fill these gaps. The first step is to explain what the private sector activities of EUCs are all about and what motivates them (Sect. 2). In a second step, the chapter describes the distortions of competition that can potentially arise from EUCs' private sector activities. The individual distortions are illustrated with concrete examples from the field of activity of the EUCs (Sect. 3). In a third step, it is examined to what extent legal requirements exist for EUCs to avoid distortions of competition (Sect. 4). Finally, a fourth and last step illustrates the possible measures which can be taken by EUCs and their owners' associations over and above the legal requirements to avoid distortions of competition and ward off accusations thereof (Sect. 5).

\section{Private Sector Activities of EUCs}

\subsection{Distinction from Public Tasks of EUCs}

Public tasks are undertakings defined by the legislator to be fulfilled on its behalf. ${ }^{7}$ The opposite case is when EUCs become active in the private sector by carrying out entrepreneurial activities outside the fulfillment of public tasks. ${ }^{8}$

There are about 630 EUCs in Switzerland. Their fields of activity differ greatly. For example, several EUCs are organized as multi-utility companies and operate not solely electricity networks but also water, gas, district heating or telecommunications networks. ${ }^{9}$ Some EUCs produce their own electricity, while others obtain all their electricity requirements from upstream suppliers. ${ }^{10}$ While the business

\footnotetext{
${ }^{6}$ See Baumann (2019), p. 85 et seq. and 137 et seq. for a comprehensive overview.

${ }^{7}$ Rütsche (2013), p. 157 et seq.; Rütsche (2016), p. 79; similar also the definition in Federal Council (2017a), p. 1895, according to which public tasks are all those tasks which the state has to fulfill on the basis of a legal statute.

${ }^{8}$ This reflects our understanding. In contrast to this, the prevailing doctrine contrasts private sector state activity with entrepreneurial state activity in the monopoly sector (see Krähenmann 1987, p. 122; Reich 2009, n. 909; Rhinow et al. 2011, § 18, n. 38; Vogel 2000, p. 22 and 75).

${ }^{9}$ For a summary history of EUCs, see Reich (2009), p. 205 et seq.

${ }^{10}$ Swiss Federal Office of Energy (2018b), p. 15 et seq.
} 
activities of EUCs differ in detail, the common feature of EUCs is that they generally operate their own distribution network and supply electricity to end consumers. ${ }^{11}$

Distribution network operation includes the obligation to connect end consumers in the respective network area to the electricity network and to ensure its maintenance and renewal. ${ }^{12}$ Distribution network operators thus perform a public task that has been assigned to them by the respective canton on the basis of federal law. ${ }^{13}$

Under current legislation, electricity supply, i.e. the delivery of electricity, can be divided into the universal service and the free market. In the universal service pursuant to Art. 6 of the Swiss Electricity Supply Act (Stromversorgungsgesetz), customers whose annual consumption is below the threshold of $100 \mathrm{MWh}$ per year (so-called "fixed end consumers") and who are therefore not free to choose their provider are supplied with electricity at "reasonable tariffs" by the state-designated local distribution network operator. In the free market, on the other hand, end consumers who exceed the above-mentioned consumption threshold are free to choose their electricity provider (Art. 6 para. 2 and para. 6 Swiss Electricity Supply Act). End consumers who would in principle be entitled to a free choice of provider but do not claim market access remain in the universal service with the fixed end consumers. ${ }^{14}$ Since Art. 6 para. 1 of the Electricity Supply Act stipulates that the local distribution network operator has a supply obligation vis-à-vis the fixed end consumers and the consumers who renounce market access, the universal service of electricity is correctly qualified as a public task by legal doctrine and case law. ${ }^{15}$

In addition to operating the distribution network and providing the basic electricity supply, some utility companies also fulfill other public tasks. Examples include waste disposal, water and gas supply, maintenance of public lighting and operation of fiber optic networks. ${ }^{16}$

For example, the Werke Fehraltorf utilities are responsible not only for electricity supply and distribution network operation but also for water supply, waste disposal and road maintenance in the municipality of Fehraltorf. ${ }^{17}$ In

(continued)

\footnotetext{
${ }^{11}$ Electricity Commission (2018), p. 28; Swiss Federal Office of Energy (2018b), p. 12.

${ }^{12}$ Jäger and Scheidegger (2016), Art. 5 para. 1-4, Electricity Supply Act, n. 8.

${ }^{13}$ Föhse (2018), p. 1242; see also Stöckli (2016), p. 184 and 192.

${ }^{14}$ See Föhse (2018), p. 1236; Scholl (2015), n. 13.24.

${ }^{15}$ BGE 144 III 111, E. 5.2; VGer BE 100.2017.247 of 12 January 2018, E. 3.3; Diebold and Ludin (2018), n. 85; Föhse (2015), p. 142; see further Rütsche (2013), p. 160.

${ }^{16}$ Whether the construction and operation of fiber optic networks are public tasks to be performed by an EUC or an activity that should be carried out by the EUC, is to be examined according to applicable legal provisions.

${ }^{17}$ See http://www.fehraltorf.ch/werke/dokumente/?navid=119623119623.
} 
turn, the City of Zurich's electricity utility ewz was given the task of building and operating a fiber optic network by the city council under a performance mandate. $^{18}$

\subsection{Examples of Private Sector Services Provided by EUCs}

In addition to operating the distribution network and fulfilling other public tasks, utility companies are economically active in areas that do not constitute public tasks. ${ }^{19}$ The extent to which such private sector services are offered varies considerably from one EUC to another. ${ }^{20}$

Numerous utility companies offer homeowners comprehensive services in the planning, installation and maintenance of photovoltaic systems.

For example, Stadtwerk Winterthur offers an "all-round carefree package" which includes planning, financing, installation of the solar system and obtaining the necessary permits. ${ }^{21}$

Many EUCs also offer e-mobility solutions, such as the installation of home charging stations for electric vehicles. This service is also offered along with the assembly of photovoltaic systems. ${ }^{22}$

The revised Energy Act created the regulatory framework for "prosumer" consumption of solar power, whereby prosumer consortia were made possible. ${ }^{23}$ However, the accounting for the electricity consumption and production by the respective

\footnotetext{
${ }^{18}$ See Resolution by the Municipal Council Zurich of 20 December 2006 (Nr. 2006/200). See for another example the EUC Eniwa, which has been mandated by the city of Aarau with the supply of water, electricity, gas and heating/cooling (City Council Aarau 2000, p. 1 et seq.).

${ }^{19}$ See Sect. 2.1.

${ }^{20}$ See also the examples mentioned in Vaterlaus et al. (2017), p. 35.

${ }^{21} \mathrm{See}$ https://stadtwerk.winterthur.ch/privatkundschaft/angebote/fotovoltaik. Similar services are being offered by Industrielle Werke Basel (IWB) (available at https://www.iwb.ch/Fuer-Zuhause/ E-Mobilitaet/Laden-mit-Solarstrom.html), Romande Energie (available at https://www.romandeenergie.ch/particuliers/habitat-et-services-energetiques/panneaux-solaires-photovoltaiques) or BKW (available at https://www.bkw.ch/unsere-kompetenzen/building-solutions/solarenergie).

${ }^{22}$ See for example the offers by IWB (available at https://www.iwb.ch) and Romande Energie (available at https://www.romande-energie.ch).

${ }^{23}$ See Art. 16 and 17 Energy Act (Energiegesetz).
} 
users is associated with difficulties. Numerous utility companies compete with private providers to offer billing solutions for self-consumption of solar power. ${ }^{24}$

A wide range of offers in the field of building services engineering represents a broad private sector field of activity for EUCs. Building services engineering consists of all the technical installations in a building and thus includes in particular the sanitary, heating, air conditioning, ventilation, high and low voltage systems. In this context, utility companies offer electrical and plumbing services as well as heating installations, lighting solutions and alarm systems. ${ }^{25}$

Several utilities offer so-called energy contracting solutions. In this case, the EUC assumes responsibility for the planning, construction, operation and maintenance of the heating system or heating network. The customer undertakes to purchase a certain amount of energy annually at a calculable price. He does not become the owner of the heating system and does not have to worry about its maintenance. ${ }^{26}$

A particularly illustrative case of private sector activity is when utilities sell household and electrical appliances.

For example, Groupe E advertises a "wide range" of household appliances, including refrigerators, dishwashers, irons, coffee machines, grills, steam cleaners and vacuum cleaners. ${ }^{27}$

The construction and operation of a fiber optic network may be a public task. On the other hand, utilities become private sector operators when they offer their own data network products.

\footnotetext{
${ }^{24}$ See for a detailed analysis Probst et al. (2019), p. 7 et seq.

${ }^{25}$ Illustrative in this regard is the owner strategy for Stadtwerk Winterthur (Stadtwerk Winterthur 2013), p. 5, which obliges Stadtwerk Winterthur to provide services in the areas of heating, plumbing and electricity installations and to offer a 24-hour service hotline for these services; see further the respective services offered by CKW (available at https://www.ckw.ch) and by EKZ (available at https://www.ekz.ch).

${ }^{26}$ See the respective services offered by EKZ (available at https://www.ekz.ch/contracting), SAK (available at https://www.sak.ch/private/prosumer/energiecontracting) or Stadtwerk Winterthur (available at https://stadtwerk.winterthur.ch/geschaeftskundschaft/angebote/energie-contracting).

${ }^{27}$ See https://shop.groupe-e.ch/de/.
} 
For example, various EUCs offer their own internet services, which can be obtained with additional options for $\mathrm{TV}$ and telecommunications. ${ }^{28}$ Elektrizitätswerk Altdorf in turn offers its own cloud solution for data storage. $^{29}$

It is hardly surprising that EUCs also offer electricity products for the already liberalized electricity market. ${ }^{30}$ Larger EUCs, such as Canton of Zurich's EKZ, also offer smaller utilities support services for electricity procurement. ${ }^{31}$

\subsection{Why Do EUCs Become Active in the Private Sector?}

One of the main reasons for the private sector activities of EUCs is the partial market liberalization that has already taken place and the intention to fully open the electricity market. The partial liberalization of the market has put the EUCs in a difficult position between private sector activity and the fulfillment of public tasks. As distribution network operators, energy utility companies must continue to operate the network and provide the basic energy supply as part of their public tasks. ${ }^{32}$ At the same time, however, they face private competition with regard to large customers who make use of free market access. Liberalization has also put pressure on the margins for electricity prices charged by EUCs. ${ }^{33}$ As electricity as a product is difficult to differentiate, price adjustments are necessary to keep and win customers in the liberalized environment. ${ }^{34}$ Against this background, the establishment of new business areas in private sector markets is considered strategically necessary in order to compensate for the loss of income from traditional fields of activity and to secure the company's existence in the long term. ${ }^{35}$

\footnotetext{
${ }^{28}$ See the respective services offered by IWB (available at https://www.iwb.ch/Fuer-Zuhause/ Telekom/IWB-Internet.html), Eniwa (available at https://www.eniwa.ch/de/internet.html) or Groupe $E$ (available at https://www.groupe-e.ch/de/intelligente-loesungen/multimedia/ privatkunden).

${ }^{29} \mathrm{See}$ https://www.ewa.ch/privatkunden/daten-produkte/urcloud.

${ }^{30}$ See for an example the services offered by EKZ (available at https://www.ekz.ch) and CKW (available at https://www.ckw.ch).

${ }^{31}$ See https://www.ekz.ch/de/unternehmen/target/evu.html.

${ }^{32}$ See Sect. 2.1.

${ }^{33}$ See Graf and Waldmeier (2016), p. 13; Sonderegger (2014), p. 27.

${ }^{34}$ See Swiss Federal Office of Energy (2018b), p. 42. 67\% of the customers with free market access (which, however, account for $80 \%$ of the electricity consumed by free customers) have left the universal service (Swiss Federal Office of Energy 2018b, p. 62).

${ }^{35}$ Baumann (2019), n. 91; Vaterlaus et al. (2017), p. 35; see further Vogel (2000), p. 7, and Bürer et al. (2021), p. 219.
} 
In addition, the Energy Strategy 2050 has shifted the focus of the energy business. ${ }^{36}$ Alongside the classic universal service, new services such as energy consulting or contracting offers for photovoltaic systems and heat pumps are coming to the fore. Owner communities are expected to give their utilities a leading role in improving energy efficiency and implementing renewable energies. ${ }^{37}$ The efforts of energy supply companies in this respect are considered ${ }^{38}$ essential for the implementation of the Energy Strategy 2050 and are therefore receiving special attention.

For example, in a benchmarking project of the Swiss Federal Office of Energy (SFOE), contracting services for PV systems and heat pumps by utilities are considered to make a positive contribution to energy efficiency and the promotion of renewables. ${ }^{39}$ In this respect, there is also political pressure for EUCs to move into business areas such as electromobility, for example, whose profitability prospects are negative or difficult to predict. ${ }^{40}$

In addition, imminent liberalization and advancing technology are opening up new business fields that overlap the areas of public service and the free market. The focus is on offers under the overarching theme "smart energy", which coordinate energy production, energy consumption and energy infrastructure according to demand. ${ }^{41}$

Furthermore, within the framework of the liberalization of the electricity market, the utilities and their management have been granted greater autonomy by their public owners. ${ }^{42}$ Against the backdrop of declining earnings in the traditional business area, it makes sense for the managers of utility companies to take advantage of this additional entrepreneurial scope in private sector markets. There are also incentives for managers of public enterprises to expand the scope of activities of the public enterprise, as the size of the enterprise is sometimes seen to reflect on the capabilities of the management. ${ }^{43}$

Finally, the granting of additional entrepreneurial leeway is likely to take place against the background that the public owners hope that this will secure long-term

\footnotetext{
${ }^{36}$ Vaterlaus et al. (2017), p. 35.

${ }^{37}$ See for example Municipal Council Bern (2017), p. 1, according to which ewb must position itself as an implementer of renewable energies; see further Enz (2018), p. 1 et seq. and 11, according to whom the canton's ownership strategy requires SAK to take action in the field of efficient energy use.

${ }^{38} \mathrm{EY}$ (2017), p. 2.

${ }^{39}$ See Vettori et al. (2018), p. 4 and 60.

${ }^{40}$ See with regard to the profitability of charging stations State Council Basel-Stadt (2019), p. 11 and 25 , where it is noted that private operators are not currently setting up charging infrastructures, as the high investment costs cannot be recouped.

${ }^{41}$ See with regard to "smart energy systems" Lund et al. (2017), p. 560.

${ }^{42}$ See Sonderegger (2012), p. 16; see also Vaterlaus et al. (2017), p. 29.

${ }^{43}$ Sappington and Sidak (2003), p. 500.
} 
revenues for the public sector. The profits of EUCs can be of considerable importance for the budget of the community concerned. ${ }^{44}$ If the revenues of EUCs fall, unpopular budget cuts or tax increases might become inevitable. ${ }^{45}$ Certain communities thus explicitly expect their EUCs to become active in private sector markets. ${ }^{46}$

\section{Distortions of Competition}

From an economic point of view, it is problematic if public companies-utility companies in particular - are unjustifiably privileged in the private sector compared to private providers. Unjustified competitive advantages can significantly impair the allocative efficiency in the market economy and thus reduce the welfare of society as a whole. ${ }^{47}$ In particular, there is a risk that, as a result of unjustifiably privileged EUCs, efficient private operators will be forced out of the market or privately owned companies will be deterred from entering it. ${ }^{48}$

Unjustified competitive advantages are those that are not attributable to the EUCs' own contributions but that rather result from the fact that EUCs are controlled by the public authorities and/or perform public tasks. In this context, the term "staterelated competitive advantages" is also aptly used. ${ }^{49}$ The following provides an overview of the state-related competitive advantages that can be expected from private sector activities of EUCs.

\subsection{Financial Advantages}

EUCs may have lower financing costs for their private sector activities compared to private providers. There are potential advantages in both borrowing and raising equity.

EUCs benefit from lower borrowing costs if they are granted low-interest loans at non-market conditions by the community or state-controlled institutions.

\footnotetext{
${ }^{44}$ Illustrative in this regard are the comments made by a politician of the city council in Bern with regard to the ownership strategy of ewb. The politician states that ewb delivers great profits of over CHF 30 million to the city treasury every year and that without this contribution the City of Bern would not be able to fulfill its public tasks (Council Secretariat City of Bern 2006, p. 681).

${ }^{45}$ For instance, the City of Bern had to compensate for budget shortfalls resulting from lower distributions by ewb (Municipal Council Bern 2016).

${ }^{46}$ The State Council of the Canton of Basel-Stadt explicitly expects IWB to become entrepreneurially active outside its public tasks (State Council Basel-Stadt 2018, p. 4).

${ }^{47}$ See Baumann (2019), n. 252 et seq.; Friederiszick (2008), p. 652 et seq.

${ }^{48}$ See Friederiszick (2008), p. 653; Geddes (2004), p. 29; Sappington and Sidak (2004), p. 14.

${ }^{49}$ See Diebold (2014), p. 221; Federal Council (2017b), p. 9.
} 
For example, the City of Bern raises capital on the financial market to the benefit of its utility Energie Wasser Bern (ewb). Due to the city's positive rating, ewb benefits from favorable interest rate conditions. In principle, ewb must compensate the risk imposed on the City of Bern by the raising of capital and the more favorable interest conditions in the form of an interest margin to the City of Bern. However, due to the tense market environment, the City of Bern recently decided not to charge the interest margin, which resulted in a competitive advantage for ewb. ${ }^{50}$

In addition, EUCs are granted more favorable conditions for borrowing if lenders assign them a higher credit rating due to their proximity to the state. For example, a higher creditworthiness may result from the fact that income or assets from the EUC's public tasks serve as collateral. ${ }^{51}$ In addition, existing explicit or implicit state guarantees have a positive effect on the creditworthiness of EUCs. ${ }^{52}$

Not only in terms of borrowing costs but also in terms of equity capital costs, EUCs can have state-related competitive advantages. Private competitors have to pay interest on the equity provided to them by their owners to cover the investment risk. Private providers must generate a profit to pay such interest on equity. Consequently, they include a corresponding profit mark-up in their prices. If the public owners, on the other hand, do not demand an adequate return on equity, the EUC can offer its goods and services without the necessary profit component and thus at potentially lower prices than its private competitors. ${ }^{53}$

Sometimes the regulations by the public owners explicitly allow the waiver of a profit component. ${ }^{54}$ It is similarly problematic if the public owners do not specify profit, dividend or return on equity targets for the utility company. ${ }^{55}$ In this case, there is a risk that EUCs will not include a (sufficient) profit margin in their private sector offers.

\footnotetext{
${ }^{50}$ See Municipal Council Bern (2016).

${ }^{51}$ For instance, electricity distribution networks or utilities could be pledged. However, certain EUCs are not allowed to pledge their distribution networks (see Art. 3 para. 1 ewz regulation [Verordnung über ewz]).

${ }^{52}$ Geddes (2004), p. 30 et seq.; Nielsen (1981), p. 58; see also Waldmeier (2018), n. 538. Explicit state guarantees in favor of EUCs exist if the liability of the community for the EUC is stipulated by law. According to a study by Vaterlaus et al. (2017), p. 37, 30\% of urban EUCs have an explicit state guarantee. In the case of implicit state guarantees, in contrast to explicit state guarantees, there is no legal liability of the community, but it can be concluded from the specific circumstances that the state will accept responsibility for the debts of the EUC.

${ }^{53}$ See Baumann (2019), n. 198 et seq.; Herrmann (2014), p. 413; see with regard to the relevance of the profit margin in public sector transportation Abegg, Seferovic (2018), n. 9 et seq.

${ }^{54}$ For instance, ewb must set cost-covering prices for its private sector services (Art. 13 ewb regulation [ewb-Reglement]).

${ }^{55}$ See Baumann (2019), n. 200.
} 
Finally, there may be financing advantages from hybrid activity if EUCs can use the income from public service activities to make investments in their private sector activities. This is particularly problematic if the margins in the private sector do not allow the private providers to make corresponding investments and if the borrowing and equity capital required for this would also be too expensive at a risk-adjusted interest rate. $^{56}$

It is argued, for example, that without the income from the monopoly business of Bern's power supplier, Bernische Kraftwerke (BKW) would not have had the necessary financial resources and stability to acquire various companies in the building technology sector. ${ }^{57}$

\subsection{Tax and Regulatory Advantages}

Private sector activities of EUCs may be unjustifiably favored by lower or no taxation. ${ }^{58}$ A low tax burden on EUCs' private sector activities may result mainly from their legal form. The Confederation, the cantons and the communes, as well as the public institutions of these communities, are exempt from both direct federal taxes and, usually, from cantonal and communal taxes. ${ }^{59}$ This means that dependent EUCs in particular, but also EUCs with the legal form of a legally independent institution, are not taxable, even if they carry out private business activities. ${ }^{60}$ This unacceptable competitive advantage can be reduced by a provision in the organizational decree according to which the utility is liable to pay tax on its private economic activities. ${ }^{61}$

In addition to tax advantages, regulatory advantages for EUCs' private sector activities mainly offer benefits in the form of simplified licensing procedures, legal exemptions, specific bankruptcy decrees or special rights. ${ }^{62}$

\footnotetext{
${ }^{56}$ Baumann (2019), n. 201 et seq.

${ }^{57}$ Schneider (2016), p. 647 et seq.

${ }^{58}$ See Capobianco, Christiansen (2011), p. 5; see further Flatt and Zindel (2017), p. 1 et seq.

${ }^{59}$ Art. 56 let. a-c Federal Act on Direct Federal Taxation (Bundesgesetz über die direkte Bundessteuer).

${ }^{60}$ See Mayoraz (2018), n. 556. 17\% of EUCs that have their own legal personality are constituted in the form of a public institution (Swiss Federal Office of Energy 2018b, p. 17 et seq.). On the other hand, tax exemptions for EUCs with a legal form under private law are only possible under strict conditions (see BGer 2C_206/2018 of 23 July 2019, E. 4.4).

${ }^{61}$ See Baumann (2019), n. 210.

${ }^{62}$ OECD (2016), p. 30.
} 


\subsection{Cross-Subsidies}

In the case of EUCs with hybrid activities, there is a risk that the private sector activities of the EUC will be cross-subsidized. This involves shifting costs or revenues within the EUC to the benefit of the private sector activities and to the detriment of the public sector. ${ }^{63}$

EUCs operating hybrid systems can cross-subsidize the private sector mainly by misallocating costs. ${ }^{64}$ The public sector has to bear costs that were actually incurred in the private sector. Such a cost shift occurs directly when the EUC's public service remit covers the deficit of its private sector activities at the end of the accounting period. On the other hand, it is more difficult to trace cross-subsidies that are implemented by means of common costs misallocation. Common costs are those that cannot be directly allocated to a product. ${ }^{65}$ An example of this is the cost of an EUC's head office building, which serves both areas of activity. A clear allocation of common costs to the respective market segments is not possible in many cases and is difficult for the regulatory authority to verify. ${ }^{66}$ This may provide a certain incentive for EUCs to charge too low a share of common costs to the private sector, thus crosssubsidizing it. ${ }^{67}$

\subsection{Economies of Scope}

EUCs operating hybrid systems are able to realize considerable economies of scope. These are savings in the average total costs that arise when different goods are provided together by one company. Where economies of scope exist, it is cheaper to produce two or more products together in a single company rather than separately in different companies. ${ }^{68}$

In perfect markets, economies of scope do not pose a problem because competitors could also enter the respective markets and thus benefit from the resulting cost savings. In contrast, economies of scope resulting from the hybrid activity of an EUC are problematic. As a rule, private competitors cannot enter the public domain due to legal restrictions, as the fulfillment of public tasks is regularly reserved for certain public EUCs. Private competitors are thus not in a position to realize the same

\footnotetext{
${ }^{63}$ Baumann (2019), n. 215 et seq. and 219.

${ }^{64}$ See European Commission (2010), p. 28.

${ }^{65}$ See with regard to common costs Fritsch (2018), p. 216.

${ }^{66}$ Brennan (1990), p. 40; Fritsch (2018), p. 216; Weber (1986), p. 420 et seq.

${ }^{67}$ See Geddes (2004), p. 30.

${ }^{68}$ See Fritsch (2018), p. 171 et seq.; Ghazarian (2018), p. 22; Peeperkorn and Verouden (2014), n. 1.49 .
} 
economies of scope and are consequently exposed to higher costs than their hybrid competitors. $^{69}$

In principle, utilities can realize economies of scope across their entire value chain. If the private and public sectors need the same inputs, cost savings can be achieved through joint purchasing. Examples include volume discounts on the purchase of computers or vehicles or discounts in connection with joint office space rentals. $^{70}$

Furthermore, an EUC can realize economies of scope if infrastructures, means of production or services can be used jointly by its private and public sectors. ${ }^{71}$ Examples of this are the shared use of websites, vehicles, tools, software programs, HR departments or warehouses.

Economies of scope also result from the bundled offer of products from the private and public sectors. A bundled offer of several products by one utility company may well meet a customer need to obtain all services from one single source (so-called "one-stop shopping"). ${ }^{72}$ Cost advantages arise for the utility, for example through the joint use of sales staff or joint invoicing. The cost savings can then be (partially) returned to the customers for acquisition purposes.

For example, Lucerne's utility Energie Wasser Luzern (ewl) announced a new type of combined product at the end of 2017, which encompasses internet products and electricity that can be purchased for a monthly flat rate. A combination discount is granted, whereby customers pay CHF 150 less per year on a cumulative basis. ${ }^{73}$

This last example highlights the issue of economies of scope in hybrid activities of EUCs, since private competitors cannot make a corresponding combined offer (with the basic supply of electricity plus internet) to fixed end consumers.

Finally, economies of scope for EUCs can also derive from the joint use of intangible assets. An EUC can use its brand, which was initially created and strengthened in the public sector, for products and services in the private market (so-called "umbrella branding"). ${ }^{74}$ Umbrella branding has the advantage for EUCs that they do not have to build a new brand for their products offered in the private sector. This makes it easier for EUCs to enter private sector markets. Similarly, EUCs can use umbrella branding to transfer their high image recognition and trust values from the public sector to their private sector offerings. ${ }^{75}$ It has been found that

\footnotetext{
${ }^{69}$ See Ghazarian (2018), p. 52 et seq.; Sappington and Sidak (2004), p. 13.

${ }^{70}$ See Baumann (2019), n. 232.

${ }^{71}$ See Barney and Hesterly (2015), p. 217.

${ }^{72}$ See Baumann (2019), n. 235 and 238.

${ }^{73}$ Ewl (2017).

${ }^{74}$ See for a detailed discussion of umbrella branding Baumann (2019), n. 234.

${ }^{75}$ See Scheda (2014), p. 34.
} 
although "independent customers" often show a willingness to switch from the universal service to the market offer, they often remain with their incumbent EUC as it enjoys a high degree of credibility. ${ }^{76}$

\subsection{Information Advantages}

A further competitive advantage resulting from proximity to the state can come in the form of information advantages for EUCs. Due to their closeness to the state, their obligation to fulfill public tasks and personnel interrelations, EUCs have access to business-relevant information that is not available to private providers. ${ }^{77}$ In particular, EUCs can potentially access customer data from the public sector, which allows them to tailor their own private sector offerings to specific customer needs.

For example, employees of the utility Elektrizitätswerk Schaffhausen used customer addresses from the monopoly sector for a marketing campaign for solar systems. ${ }^{78}$

Significant information advantages can result for EUCs from their function as (distribution) network operators. As distribution network operators, EUCs are given exclusive insights into the functioning and future development of the electricity system. They may therefore have an information advantage over private competitors, for example in the areas of storage requirements and flexibility. ${ }^{79}$ In addition, network operators may obtain data from the customers' network connection, which can be used for new business models. ${ }^{80}$ These include customized products, the sale of data to third parties (e.g. insurance companies) and new services. ${ }^{81}$

As a result of information advantages, an EUC can also give preference to its own private sector activities over private competitors.

For example, Energie Wasser Bern (ewb), in its function as a distribution network operator, must periodically request the owners of electrical

(continued)

\footnotetext{
${ }^{76}$ Swiss Federal Office of Energy (2018b), p. 62 et seq.

${ }^{77}$ See for a detailed discussion Baumann (2019), n. 247 et seq.

${ }^{78}$ The employees were subsequently fined by the Swiss Federal Office of Energy for this misconduct (see Vonplon 2019, p. 13).

${ }^{79} \mathrm{Kratz}(2018)$, p. 158 et seq.

${ }^{80}$ Kratz (2018), p. 159.

${ }^{81}$ Beyeler (2017), p. 59.
} 
installations to have their installations inspected. In principle, the owners may entrust inspections to any company authorized to do so. Unless the owners had previously decided on a particular inspection company, ewb passed on almost all inspection assignments to its own subsidiary. ewb also expressly referred on its website to the inspection offers of its own subsidiary but not to offers from other private suppliers. ${ }^{82}$

\section{Legal Requirements for EUCs to Avoid Distortions of Competition}

\subsection{Constitutional Requirements}

According to prevailing legal doctrine and case law, the private sector activities of state-owned companies and thus also especially those of EUCs must be conducted in a manner that is neutral to competition, respectively in a manner that does not distort competition. ${ }^{83}$ The requirement of competitive neutrality results from the interaction of Art. 27 and 94 of the Swiss Federal Constitution (Bundesverfassung). ${ }^{84}$ The private sector activities of the EUCs may be considered in compliance with the requirement of competitive neutrality if they have to face the same competitive conditions as private competitors do. Distortions of competition in the form of legal and de facto privileges for the private sector activities of EUCs must therefore be avoided. In particular, legal advantages such as the exemption from tax and insurance obligations, the granting of explicit state guarantees or exemptions from the relevant economic supervision and competition law are problematic. ${ }^{85}$ Furthermore, de facto privileges such as the preferential provision of infrastructure, implicit state guarantees and cross-subsidization also conflict with the requirement of competitive neutrality. ${ }^{86}$

Although the requirement of competition neutrality is thus generally easy to understand, its concrete implementation and enforcement is much more difficult:

\footnotetext{
${ }^{82}$ See Competition Commission (2014), p. 79 et seq, n. 156 et seq., ewb.

${ }^{83} \mathrm{See}$ for an overview of the requirements for private sector activities by the state Hangartner (2007), p. 241 et seq.; Hänni and Stöckli (2013), n. 1717 et seq.; Krähenmann (1987), p. 209 et seq.; Reich (2013), p. 1410; Rhinow et al. (2011), § 18 n.53 et seq.; Tschannen et al. (2014), § 10 n. 24 et seq.; Vogel (2000), p. 109 et seq., 116 and 125; BGE 138 I 378, E. 7-9.

${ }^{84}$ Schönbächler (1998), n. 86; Vogel (2000), p. 123; BGE 143 II 425, E. 4.2.

${ }^{85}$ See Hangartner (2007), p. 245 et seq.; Hänni, Stöckli (2013), n. 1720; Vogel (2000), p. 208 et seq. ${ }^{86}$ Rhinow et al. (2011), § 18 n. 106; Hangartner (2007), 245 et seq.; Uhlmann (1997), p. 213 et seq.; BGE 138 I 378, E. 9.1.
} 
Firstly, it is apparent from case law that certain distortions of competition are not considered at all, or only to a certain extent, to be a violation of competitive neutrality. In fact, the case law on this matter does not always appear to be entirely consistent. ${ }^{87}$ In the Glarnersach decision, the Federal Supreme Court classified factual competitive advantages, such as access to customer data in the monopoly sector or the possibility of offering combination products, as modest at best-which is why a significant distortion of competition was not considered to exist. ${ }^{88}$ In contrast, in a more recent decision the Federal Supreme Court rightly assumed that the synergy effects resulting from the parallel fulfillment of a public task and the provision of private sector services constitute a distortion of competition to the detriment of competitors operating purely in the private sector. ${ }^{89}$

Secondly, it is difficult to conclusively derive from the condition of competitive neutrality what concrete measures are to be taken to avoid the respective distortions of competition. The handling of cross-subsidization provides an example of this. According to the Federal Supreme Court in the Glarnersach decision, the financial separation of the (public) monopoly sector from private sector services was sufficient for the enforcement of the ban on cross-subsidies. ${ }^{90}$ In this context, the Supreme Court considered cross-subsidies via common cost allocation to be "hardly plausible" if the allocation keys are based on realistic cost estimates. ${ }^{91}$ On the other hand, purely financial or accounting separation is considered insufficient in legal doctrine, which indeed postulates that, due to the uncertainties in cost allocation, a strict organizational separation of the two areas would also be required in order to effectively prevent cross-subsidies. ${ }^{92}$

Overall, the requirement of competitive neutrality so far results in only a few specific requirements for how EUCs organize their private sector activities. Clearly inadmissible are cross-subsidies, which means that the public service remit must be financially separated from the EUC's private sector activities. Tax, financing, economies of scope and information advantages are problematic in light of the requirement of competitive neutrality. However, concrete and consistent requirements for dealing with them cannot yet be derived from the existing case law.

\footnotetext{
${ }^{87}$ See Baumann (2019), n. 342 et seq.

${ }^{88}$ BGE 138 I 378, E. 9.4; see for critical discussions of this decision Hangartner (2012), p. 1821; Kraemer and Stöckli (2013), p. 29; Reich (2013), p. 1411 et seq.; see further Weber and Volz (2013), n. 2.650. It is, however, important to note that in the Glarnersach decision, the Federal Court only subjected the statute in question to a very broad review (so-called abstract norm review, in German "abstrakte Normenkontrolle").

${ }^{89}$ See BGer 2C_1007/2015 of 10 May 2016, E. 5.2.

${ }^{90}$ BGE 138 I 378, E. 9.2.

${ }^{91}$ BGE 138 I 378, E. 9.3.3.

${ }^{92}$ Abegg and Frei (2018), p. 152; Kraemer and Stöckli (2013), p. 38 et seq.; Stoffel and Murith (2019), p. 34.
} 


\subsection{Antitrust Law}

Electricity utilities, irrespective of their legal form, are subject to antitrust law if they carry out private sector activities outside their monopoly areas. ${ }^{93}$ In the case of EUCs, it can be assumed in general that they have a dominant position on the market because of their public tasks and any monopoly rights associated with them. In this context, dominant companies behave unlawfully if, by abusing their dominant position in the market, they hinder other companies from starting or continuing to compete or disadvantage trading partners. ${ }^{94}$ According to the practice of the competition authorities, this dominant position can also be abused in upstream or downstream or neighboring private markets. ${ }^{95}$ If EUCs have a dominant position in the market, it must be examined to what extent the distortions of competition (described in Sect. 3 above) are to be qualified as abuse of a dominant position within the meaning of Art. 7 of the Swiss Cartel Act (Kartellgesetz). ${ }^{96}$

In the case of cross-subsidization, the discrimination of trading partners (Art. 7 para. 2 let. b Swiss Cartel Act) as well as the unlawful practice of price undercutting (Art. 7 para. 2 let. d Swiss Cartel Act) may be of relevance. ${ }^{97}$

In the case of discrimination of trading partners (Art. 7 para. 2 let. b Swiss Cartel Act), the EUC's own private sector division is given preference over its private competitors. The private sector division purchases services from the EUC at crosssubsidized conditions, while private providers have to pay the full price. However, this abuse presupposes that the cross-subsidized services in question are actually offered to or demanded by private competitors. This will often not be the case, particularly with respect to typical internal group or company services in the areas of IT, personnel administration, marketing or accounting. ${ }^{98}$

By contrast, in the case of price undercutting (Art. 7 para. 2 let. d Swiss Cartel Act), cross-subsidization is used to undercut prices or other trading conditions in order to weaken or drive current competitors out of the market or to prevent potential competitors from entering the market. ${ }^{99}$ Abusive price undercutting is to be assumed if the revenues generated are not sufficient to cover the company's own costs in the

\footnotetext{
${ }^{93}$ Art. 2 para. 1 Swiss Cartel Act. See Competition Commission (2014), p. 79 et seq., n. 22 et seq., ewb; see also BGE 138 I 378, E. 9.3.3 and 9.4; see further Ducrey (2009), p. 76.

${ }^{94}$ Art. 7 para. 1 Swiss Cartel Act.

${ }^{95}$ Competition Commission (2014), p. 79 et seq., n. 66 et seq., ewb; Stäuble and Schraner (2018a), Art. 7 n. 239.

${ }^{96}$ See Competition Commission (2014), p. 79 et seq., n. 81, ewb.

${ }^{97}$ Competition Commission (2014), p. 79 et seq., n. 88 and 91. ewb; Borer (2011), Art. 7, n. 18. According to Amstutz, Carron (2010), Art. 7 n. 242, cross-subsidization may also constitute a form of unfair conditions of trade within the meaning of Art. 7 para. 2 let. c Swiss Cartel Act.

${ }^{98}$ See Competition Commission (2014), p. 79 et seq., n. 88 et seq., ewb; Stäuble and Schraner (2018b), Art. 7 n. 324.

${ }^{99}$ Competition Commission (2014), p. 79 et seq., n. 91, ewb; Zäch (2005), n. 684.
} 
long term. ${ }^{100}$ After successfully forcing the competitors from the market, the utility can then raise prices above the competitive level and compensate for losses (so-called "recoupment"). ${ }^{101}$ In addition to recoupment, abusive undercutting also requires that an undercutting strategy is implemented and that there are no justifications for the undercutting. Cross-subsidization on its own, however, does not constitute a requirement for price undercutting in the sense of Art. 7 para. 2 let. d Swiss Cartel Act. But it does make undercutting financially more bearable for the EUC employing the strategy, especially if funds from the public sector are used for cross-subsidization. ${ }^{102}$

According to the existing practice of the Secretariat of the Swiss Competition Commission (Sekretariat der Wettbewerbskommission WEKO), there are indications of abusive cross-subsidization, as can occur in the case of unequal treatment of trading partners or price undercutting, if (i) the private sector activities of EUC receive services from that EUC at non-market conditions, (ii) the EUC obtains services from the private sector at too high a price or without justification by not complying with public procurement law, or (iii) structural deficits of the private sector activities are covered with funds from the public task remit of the EUC. ${ }^{103}$

An abuse of market power within the meaning of Art. 7 Swiss Cartel Act can also exist when information advantages are being exploited by the EUC. In the case of hybrid activities, the transfer of information from the public sector activities to the private sector activities is problematic because the EUC has the relevant information due to its obligation to fulfill a public task and not due to its own economic capabilities. If the transfer of information within the EUC is based on an obstructionist strategy aimed at forcing competitors from a market or keeping them out of the private market, an abuse of a dominant position is likely to be assumed. ${ }^{104}$ According to the Secretariat of the Competition Commission, an impermissible data exchange can also consist of an EUC recommending its own private sector services to its customers in the public sector. ${ }^{105}$

EUCs may unlawfully impede competitors in the meaning of Art. 7 para. 2 let. f Swiss Cartel Act if they couple private sector offers with services from the public sector. Such "coupling" can also be achieved by means of positive incentives, in particular discounts. In the case of hybrid EUCs, the abusive nature of coupling arises from the special legal status of the public service area. ${ }^{106}$ Against this

\footnotetext{
${ }^{100}$ In determining whether prices are cost-covering, it must be examined whether the company is able to cover average variable costs during the period of price undercutting (Amstutz and Carron 2010, Art. 7 n. 377).

${ }^{101}$ Amstutz, Carron (2010), Art. 7 n. 322; Borer (2011), Art 7 n. 24; Stäuble and Schraner (2018b), Art. 7 n. 436.

${ }^{102}$ See Amstutz and Carron (2010), Art. 7 n. 365 and 372; Zäch (2005), n. 684.

${ }^{103}$ Competition Commission (2014), p. 79 et seq., n. 85 et seq. and 127 et seq., ewb.

${ }^{104}$ See Competition Commission (2014), p. 79 et seq., n. 145 et seq., ewb.

${ }^{105}$ See Competition Commission (2014), p. 79 et seq., n. 156 et seq., ewb.

${ }^{106}$ See Borer (2011), Art. 7 n. 27; Vogel (2000), p. 197 et seq.; Zäch (2005), n. 702; see further Competition Commission (2011b), p. 483 et seq., n. 159, Gebäudeversicherung Bern (GVB).
} 
background, a combined product for the purchase of electricity and internet services would be problematic, especially if a combined discount is granted. ${ }^{107}$ However, combined products from private sector activities and public tasks are hardly unobjectionable from an antitrust point of view, even without the granting of discounts, as private suppliers are unable to make an equivalent offer. ${ }^{108}$

In contrast, in an older decision from the year 2011 the Secretariat of the Competition Commission had considered it unproblematic under antitrust law for a hybrid company to apply umbrella branding. In accordance with the Secretariat's practice, the use of a common umbrella brand as well as the uniform design and reciprocal linking of the group's own websites in particular are to be classified as permissible conduct. ${ }^{109}$ However, joint advertising campaigns for products of private sector activities and public services should be avoided. ${ }^{110}$

It follows from the above that the problematic practices punishable under antitrust law cover a subset of possible distortions of competition by EUCs. Distortions of competition such as cross-subsidization, information advantages and, to a lesser extent, economies of scope may form part of abusive practices, provided that the other elements of the relevant exclusionary conduct are given. ${ }^{111}$ Moreover, it is necessary that the distortions of competition do not result in an obstructive effect that is merely minor in nature. ${ }^{112}$ However, competitive advantages of EUCs that are due to state regulations, such as tax advantages and financing advantages, hardly fall within the scope of Art. 7 Swiss Cartel Act. ${ }^{113}$

\footnotetext{
${ }^{107}$ See Sect. 3.4 above with regard to a corresponding combination product intended to be launched by ewl.

${ }^{108}$ Against this background, Gebäudeversicherung Bern has undertaken not to offer any combination products (see Competition Commission 2011b, p. 483 et seq., n. 166 et seq., Gebäudeversicherung Bern [GVB]).

${ }^{109}$ Competition Commission (2011a), p. 87 et seq., n. 35, Switch/Switchplus; Competition Commission (2014), p. 79 et seq., n. 167 et seq., ewb; Competition Commission (2011b), p. 483 et seq., n. 165, Gebäudeversicherung Bern (GVB). Stoffel and Graber (2013), p. 853, on the other hand, consider the joint use of a website or a customer magazine to be actions in the grey area of competition law.

${ }^{110}$ For example, Gebäudeversicherung Bern has undertaken not to conduct any joint advertising campaigns for the compulsory buildings insurance and the private insurance offered (Competition Commission 2011b, p. 483 et seq., n. 167, Gebäudeversicherung Bern ([GVB]).

${ }^{111}$ Otherwise, the distortions of competition may still be subsumed under the general clause of Art. 7 para. 1 Swiss Cartel Act. According to Stoffel and Murith (2019), p. 45, cross-subsidizations are per se prohibited under antitrust law.

${ }^{112}$ Competition Commission (2011a), p. 87 et seq., n. 51, Switch/Switchplus.

${ }^{113}$ See Vogel (2000), p. 208 et seq.
} 


\subsection{Electricity Supply Law}

The Swiss Electricity Supply Act (Stromversorgungsgesetz) addresses the risk of EUCs transferring their market power resulting from distribution network operation to competitive areas of activity with the following unbundling requirements. ${ }^{114}$ According to Art. 10 para. 1 Swiss Electricity Supply Act, EUCs must ensure the independence of distribution network operation. To this end, the distribution network operations are to be unbundled from the other areas of activity, at least in accounting terms (Art. 10 para. 3 Swiss Electricity Supply Act). ${ }^{115}$ In addition, Art. 10 para. 2 Swiss Electricity Supply Act provides for informational unbundling, according to which economically sensitive information obtained from network operation may not be used by EUCs for other areas of activity. Finally, crosssubsidization between network operation and the other areas of activity is explicitly prohibited. ${ }^{116}$ The Federal Electricity Commission (ElCom) monitors compliance with these provisions. ${ }^{117}$ Failure to comply with the requirements for accounting unbundling and the prohibition of use of sensitive information could result in fines of up to CHF $100,000 .^{118}$

Art. 10 para. 1 Swiss Electricity Supply Act expressly prohibits crosssubsidization between distribution network operation and other areas of activity. The provision aims to ensure that revenues from the network sector are not used to cross-subsidize competitive activities. ${ }^{119}$ However, the prohibition of crosssubsidization is largely unspecified. Due to the heterogeneity of the utilities, it was decided not to make specific regulatory requirements for the allocation of common costs. ${ }^{120}$ However, according to Art. 7 para. 5 Electricity Supply Ordinance (Stromversorgungsverordnung), the cost allocation keys used must be appropriate, comprehensible and recorded in writing, and they must comply with the principle of consistency. ${ }^{121}$

Informational unbundling shall prevent that EUCs have a competitive advantage over their competitors arising from the knowledge of distribution network operation. ${ }^{122}$ Economically sensitive information according to Art. 10 para. 2 Swiss Electricity Supply Act is information from the operation of electricity networks which is suitable for providing the EUC with a competitive advantage in the private

\footnotetext{
${ }^{114}$ Federal Council (2004), p. 1648.

${ }^{115}$ See also Art. 6 para. 3 and Art. 12 para. 2 Electricity Supply Act.

${ }^{116}$ Art. 10 para. 1 Electricity Supply Act.

${ }^{117}$ Art. 22 para. 1 Electricity Supply Act.

${ }^{118}$ Art. 29 para. 1 and 2 Electricity Supply Act. Accordingly, the Swiss Federal Office of Energy fined employees of Elektrizitätswerke Schaffhausen for misusing addresses from the monopoly sector for a marketing campaign for private sector activities (see Vonplon 2019, p. 13).

${ }^{119}$ See Federal Council (2004), p. 1648.

${ }^{120}$ See D'Arcy and Burri (2009), p. 133.

${ }^{121}$ See also VSE (2018), p. 10.

${ }^{122}$ Federal Council (2004), p. 1649; see also VSE (2018), p. 17.
} 
sector. ${ }^{123}$ An unjustified competitive advantage may arise if the information from the operation of the network leads, for example, to a reduction in costs, an advantage in time, an increase in revenue or an improvement in the product in the private sector activities of the utility. ${ }^{124}$ The prohibition of use of economically sensitive information includes in particular the master data (name, address, etc.) and consumption data of network users as well as related meta and structural data. ${ }^{125}$ Informational unbundling has gained in importance as a result of progressive digitalization and the introduction of intelligent metering systems. ${ }^{126}$ In this context, the issue has also increasingly moved into the focus of ElCom's attention. ${ }^{127}$

The accounting unbundling of the distribution network operations from the other areas of activity serves to make the cost structure of network operations transparent to the regulator and thus preclude inadmissible cross-subsidization. ${ }^{128}$ However, the legislator has left EUCs considerable leeway with regard to the systemic implementation of accounting unbundling. ${ }^{129}$

The provisions of the Swiss Electricity Supply Act described above are hardly sufficient to comprehensively avoid cross-subsidization and information advantages. Because the legislator has deliberately refrained from organizational unbundling of the distribution network business, ${ }^{130}$ it remains permissible, for example, for the same persons to hold management positions in both the distribution network and competitive areas. ${ }^{131}$ Economically relevant information flows between the areas of activity can therefore hardly be avoided. In the case of accounting unbundling, there are considerable differences in the EUC's overhead cost allocations. This makes it more difficult to monitor the ban on cross-subsidization. Finally, economies of scope are only addressed indirectly, namely via information unbundling and the ban on cross-subsidization. Ultimately, the Swiss Electricity Supply Act does not contain any provisions on the financing of and tax advantages for energy supply companies.

\footnotetext{
${ }^{123}$ Orelli and Thomann (2016), Art. 10 n. 9.

${ }^{124}$ Orelli and Thomann (2016), Art. 10 n. 9; VSE (2019), p. 17.

${ }^{125}$ VSE (2019), p. 18; see also for a detailed list of economically sensitive data Bundesnetzagentur (2007), p. 15.

${ }^{126}$ Lang (2019), p. 3.

${ }^{127}$ Electricity Commission (2018), p. 28; Lang (2019), p. 3.

${ }^{128}$ D'Arcy and Burri (2009), p. 130; Orelli and Thomann (2016), Art. 10 n. 18; VSE (2018), p. 9.

${ }^{129}$ Orelli and Thomann (2016), Art. 10 n. 20; see further D’Arcy, Burri (2009), p. 130 et seq.; Stillfried (2010), p. 182.

${ }^{130}$ Federal Council (2004), p. 1649.

${ }^{131}$ Orelli, Thomann (2016), p. 16.
} 


\section{Measures to Avoid Distortions of Competition}

There are only few concrete guidelines for EUCs on how to deal with potential distortions of competition in their private sector activities (Sect. 4 above). This regulatory deficit weighs heavily, as on the one hand it is hardly to be expected that the private sector activities of EUCs will lose importance in the future. ${ }^{132}$ On the other hand, many of the measures proposed here may become relevant regardless, particularly with a view to a possible electricity agreement with the EU. It is to be expected that Switzerland will have to adopt the requirements of EU state aid law and the electricity acquis to the greatest extent possible in order to participate in the EU's internal electricity market. ${ }^{133}$ Distortions of competition, in particular tax and financing advantages, are incompatible with the EU ban on state aid in principle. ${ }^{134}$

The following lays out de lege ferenda measures to avoid the distortions of competition described above. ${ }^{135}$ For EUCs that want to pro-actively ensure the competitive neutrality of their private sector activities, this catalogue of measures also offers a corresponding recommendation for action already today. This is not an exhaustive list. Depending on the area of activity of the utility, there are further distortions of competition which may result in an additional need for action.

\subsection{Organizational Requirements}

Avoiding distortions of competition effectively requires a structural separation between the public tasks and the private sector activities of the EUC. Structural separation can be carried out in different gradations. It may take the form of accounting, functional, organizational or even ownership unbundling. ${ }^{136}$ At the time when the Swiss Electricity Supply Act was enacted, distribution networks were not organizationally separated due to the restrictions of smaller EUCs. ${ }^{137}$ However, the distortions of competition described above are favored by the lack of organizational separation. If the private sector activities of an EUC are considerable, legal provisions to ensure the organizational outsourcing of these activities to a

\footnotetext{
${ }^{132}$ See Sect. 2.3.

${ }^{133}$ Federal Council (2013) p. 7582; see also Mayoraz (2018), n. 547; Hofmann et al. (2021), p. 85.

${ }^{134}$ Mayoraz (2018), n. 551 and 553 et seq.; Ziegler, Moser (2019), n. 58 and 77.

${ }^{135}$ In doing so, reference is made in particular to some of the relevant EU requirements.

${ }^{136}$ See OECD (2015), p. 46 et seq.; Petrik-Haltiner (2017), p. 44.

${ }^{137}$ Federal Council (2004), p. 1649; Orelli, Thomann (2016), Art. 10 n. 8. In contrast, Art. 26 para. 1 of Directive 2009/72 of the European Parliament and the Council of 13 July 2009 concerning common rules for the internal market in electricity and repealing Directive 2003/54/EC, OJ L 211, 14 August 2009, 55-93, requires distribution network operation to be carried out by a separate company. However, Art. 26 para. 4 of the Directive 2009/72/EC allows exemptions for vertically integrated EUCs with fewer than 100,000 customers.
} 
separate company are necessary. In order to avoid tax advantages, the legal form of a private-law company limited by shares should be chosen in principle. ${ }^{138}$

However, in the case of EUCs with limited private sector activities, organizational separation may not be appropriate. In this case, the EUC should be required by law to separate the two sectors by function. To this end, the public sector and private sector activities must be managed as separate business units. ${ }^{139}$ In order to meet the requirements of the Federal Supreme Court and Electricity Supply Act regarding the financial separation of public and private sector activities, at least the accounts of the two sectors must be kept separately. ${ }^{140}$

In any case, the separation of public tasks and private sector activities requires that the public tasks to be performed by the EUC are clearly defined. In particular, expansions that are not worthwhile from an entrepreneurial point of view but politically desired by the EUC's public owners must be defined by the latter as a public task. ${ }^{141}$ The costs involved in undertaking such public tasks must be disclosed to the legislator so that it can make an informed decision on the cost-benefit ratio of the project. $^{142}$

\subsection{Financial Advantages}

If private-sector activities of EUCs are financed by means of debt (loans, credits, etc.), the law must provide that the EUC has to pay interest at market rates in order to avoid financing advantages. On the one hand, an EUC may only grant loans to its private sector business divisions or subsidiaries at normal market conditions in order not to expose itself to the accusation of abusive cross-subsidization under antitrust law. ${ }^{143}$ On the other hand, the public owners themselves can also ensure that there are no financing advantages by granting loans to an EUC for private sector activities only on market terms.

In order to determine the market rate, the interest rate that would apply to comparable private companies must be ascertained. To this end, EUCs should obtain appropriate benchmark ratings for all loans. The rating would determine the interest rate at which the public utility would have to take out the loan if it were operating as

\footnotetext{
${ }^{138}$ See Sect. 3.2; Mayoraz (2018), n. 556.

${ }^{139}$ See Finger et al. (2009), p. 22.

${ }^{140}$ See Sect. 4.3. According to Art. 4 para. 1 Directive 2006/111 of the European Commission of 16 November 2006 on the transparency of financial relations between Member States and public undertakings as well as on financial transparency within certain undertakings, OJ L 318,17 November 2006, 17-25, the costs and revenues are to be allocated by means of uniformly applied, objectively justified and clearly defined cost accounting principles.

${ }^{141}$ See OECD (2012), p. 53.

${ }^{142}$ See OECD (2015), p. 47.

${ }^{143}$ Competition Commission (2014), p. 79 et seq., n. 115, ewb.
} 
a private company. To ensure the independence of the ratings, they should not be issued by institutions that maintain a significant business relationship with the EUC.

It may prove disproportionately costly for EUCs to obtain such ratings, especially if the debt financing is negligible for the EUC's business. For this reason, it might be appropriate for the regulator to calculate the interest advantage resulting from state control for different categories of utilities. This would then be added to the interest rate actually granted in order to determine the market rate.

Interest rate adjustments are more difficult when utilities take out loans from third parties. As shown above, state guarantees in favor of EUCs lead to financing advantages. For this reason, explicit state guarantees for private sector activities of EUCs must be abolished as a first step. However, it can be presumed that even without an explicit state guarantee, third parties assume that there is a low risk of default of a state-owned utility. In order to avoid financing advantages, EUCs should be obliged to calculate the resulting interest advantage using the methods described above and then pay it to the state.

In addition, public authorities should only provide collateral for EUC loans at market conditions. Market conditions may normally be assumed if (i) the EUC is not in any financial difficulties, (ii) the collateral is linked to a specific transaction, (iii) the community also bears part of the risk and (iv) the utility pays a market price for the provision of the collateral. ${ }^{144}$

With regard to advantages in terms of return on equity, it is imperative for the community to expressly state in both the organizational decree and the owner strategy that private sector activities may only be taken up by the EUC if market returns are achieved. ${ }^{145} \mathrm{~A}$ market return corresponds to the average expected return on an investment that the market requires on the basis of generally accepted criteria, taking into account in particular the risk involved in the investment, the financial situation of the firm and the specific characteristics of the economic activity concerned. $^{146}$

For example, the calculation of the internal rate of return (IRR) is a widely accepted standard method for determining the annual return on capital. ${ }^{147}$ The same results are usually obtained when the investment decision is evaluated on the

\footnotetext{
${ }^{144}$ See n. 114 Commission Notice on the notion of State aid as referred to in Article 107(1) of the Treaty on the Functioning of the European Union C/2016/2946, OJ C 262, 19 July 2016, 1-50.

${ }^{145}$ According to Schedler et al. (2016), p. 118, the return on equity must be regulated in the owner strategy.

${ }^{146}$ See n. 102 Commission Notice on the notion of State aid as referred to in Article 107(1) of the Treaty on the Functioning of the European Union C/2016/2946, OJ C 262, 19 July 2016, 1-50.

${ }^{147}$ See n. 102 Commission Notice on the notion of State aid as referred to in Article 107(1) of the Treaty on the Functioning of the European Union C/2016/2946, OJ C 262, 19 July 2016, 1-50. The IRR takes into account the future cash flows that an investor expects to receive during the investment period. It defines the discount rate at which the capital value of several cash flows is zero.
} 
basis of its net present value (NPV). ${ }^{148}$ The target return can also be derived from the weighted average cost of capital (WACC). According to this method, an EUC must at least generate returns that exceed its capital costs. ${ }^{149}$ Ideally, EUCs generally examine their private sector projects using various methods to confirm the estimates. $^{150}$

Especially for smaller EUCs, the calculation of a target return at market conditions is likely to be a challenge. It might be appropriate then to provide guidelines to EUCs with ranges of normal market returns for relevant private sector activities.

\subsection{Tax and Regulatory Advantages}

Private activities of EUCs must be subject to the same taxation as the corresponding activities of private operators. Tax advantages of EUCs mostly result from the fact that the tax preference is linked to a legal form which is not open to private competitors. ${ }^{151}$ The maxim must be that the tax liability of EUCs has to be based on their activity and not on their organizational form. ${ }^{152}$ To this end, the organizational decrees of public law institutions must stipulate as standard that utilities are taxable as private companies with regard to their private sector activities. ${ }^{153}$

However, even with a corresponding decree, preferential tax treatment at the level of federal taxes remains in place. Against this background, it is imperative that the private sector activities of EUCs be conducted only in the legal form of companies limited by shares under private law. ${ }^{154}$ If such adaption of the legal form cannot be carried out, EUCs should be required by law to calculate the normal taxation for their private sector activities. The calculated tax advantage must then be compensated for by means of a compensatory payment to the public authorities.

If there are other regulatory advantages in favor of the private sector activities of EUCs, the relevant provisions must be repealed or adapted by the respective community. If regulatory preferences cannot be avoided, the advantage must be compensated to the community and taken into account in the pricing of the private sector offer.

\footnotetext{
${ }^{148}$ See n. 102 Commission Notice on the notion of State aid as referred to in Article 107(1) of the Treaty on the Functioning of the European Union C/2016/2946, OJ C 262, 19 July 2016, 1-50. In the case of NPVs, the difference between the positive and negative cash flows accruing during the investment period is discounted at an appropriate rate of return.

${ }^{149}$ See Art. 13 para. 3 let. b Electricity Supply Ordinance.

${ }^{150}$ See n. 105 Commission Notice on the notion of State aid as referred to in Article 107(1) of the Treaty on the Functioning of the European Union C/2016/2946, OJ C 262, 19 July 2016, 1-50.

${ }^{151}$ See Sect. 3.2.

${ }^{152}$ This is stated explicitly in the Guidelines of the Federal Council on Corporate Governance (Guideline 28) (Federal Council 2006, p. 8283).

${ }^{153}$ See Federal Council (2006), p. 8282.

${ }^{154}$ See Sect. 3.2.
} 


\subsection{Cross-Subsidies}

As described above, the current prohibition of cross-subsidization is difficult to specify and verify with regard to the more than 600 EUCs in Switzerland. The following measures can also be taken to ensure that no cross-subsidization takes place.

The law should stipulate that services between the private and public sector business divisions of an EUC must be provided at arm's length and must be set out in contractual agreements. ${ }^{155}$ In this way, EUCs can also ensure that they are not suspected of abusive practices under antitrust law in connection with crosssubsidization. ${ }^{156}$

Cross-subsidization resulting from a misallocation of overheads is particularly difficult to trace. For this reason, it is important that overhead costs are correctly broken down. In doing so, appropriate, comprehensible and written cost codes that comply with the principle of consistency must be used. As a result of the differences between the EUCs, it is hardly possible to provide uniform cost codes. However, it would be useful to use concrete, meaningful examples to show which requirements the overhead cost codes of the utility companies have to meet.

Within the framework of the "sunshine regulation" now provided for by law in accordance with Art. 22a of the Draft Electricity Supply Act, ElCom can also collect information on the relevant overhead costs (allocations) from the electricity utility companies and compare the data received. ${ }^{157}$ The results of this comparison can then be published. EUCs whose overhead costs (allocations) differ significantly from the average are motivated to make adjustments to the cost allocation or to justify their chosen method convincingly.

Finally, EUCs should regularly check whether their private business activities are free of cross-subsidies. In practice, there are various methods to do so. ${ }^{158}$ In the present case, it would make sense to follow a further development of the Faulhaber rule, as provided for in Art. 48(1) of the Swiss Postal Regulation. ${ }^{159}$ Accordingly, there is an illegal cross-subsidization if the revenue from a particular good offered by the utility in the private sector is not sufficient to cover the incremental costs of this

\footnotetext{
${ }^{155}$ See European Commission, Interpretative Note on Directive 2009/72 of the European Parliament and the Council of 13 July 2009 concerning common rules for the internal market in electricity and repealing Directive 2003/54/EC, OJ L 211, 14 August 2009, 55-93, and Directive 2009/73 of the European Parliament and the Council of 13 July 2009 concerning common rules for the internal market in natural gas and repealing Directive 2003/55/EC, OJ L 211, 14 August 2009, 94-136; European Commission (2010), p. 25.

${ }^{156}$ See Sect. 4.2.

${ }^{157}$ See Swiss Federal Office of Energy (2018c), p. 33 et seq.

${ }^{158}$ See Baumann (2020), n. 12 et seq.; Spiekermann (2010), p. 28 et seq.

${ }^{159}$ See with regard to the further development of the Faulhaber rule Baumann (2020), n. 16; Platt (2005), p. 39.
} 
good and there is a service or business division in the public sector whose revenue exceeds its stand-alone costs. ${ }^{160}$

\subsection{Economies of Scope}

In the case of economies of scope, the requirements regarding cross-subsidization and informational unbundling must always be observed. ${ }^{161}$ This means that the private sector activities of the EUC can only provide shared services such as IT services and HR support if information unbundling is guaranteed and there is no risk of cross-subsidization. ${ }^{162}$

EUCs are to be prohibited by law from offering combined products or combination discounts from the public sector and private business activities. This is already required in view of the fact that they would otherwise expose themselves to risks under antitrust law. ${ }^{163}$ "All-round carefree packages" that are offered by EUCs and include both public and private sector services must therefore be unbundled.

It can be assumed that the average customer is unaware of the fact that EUCs have public functions alongside private sector activities. ${ }^{164}$ In order to avoid unjustified advantages in this respect, it must be clearly recognizable for the customer in each case whether a service is offered by an EUC's public sector or private sector activities. It is important to rule out any likelihood of confusion between the two areas. $^{165}$

To this end, an EUC may be required by law to use a different brand in its private business activities than the one it uses for its public service activities. ${ }^{166}$ The brands must thus be designed and also deployed in such a way that customers can recognize the services of the EUC and have no doubt about which of the two areas of activity the services belong to. ${ }^{167}$ Measures to achieve this include, for example, different color choices, distinguishable fonts and the use of individual image components and unique names. ${ }^{168}$

\footnotetext{
${ }^{160}$ See Baumann (2020), n. 14 et seq., for a detailed description of incremental and stand-alone costs; see for the calculation of the stand-alone costs PostCom (2013), p. 3.

${ }^{161}$ See Sect. 4.3.

${ }^{162}$ See Bundesnetzagentur (2006), p. 19; European Commission (2010), p. 25.

${ }^{163}$ See Sect. 4.2.

${ }^{164}$ In a similar way Bundesnetzagentur (2012), p. 9.

${ }^{165}$ See Art. 26 para. 3 Directive 2009/72 of the European Parliament and the Council of 13 July 2009 concerning common rules for the internal market in electricity and repealing Directive 2003/ 54/EC, OJ L 211, 14 August 2009, 55-93; European Commission (2010), p. 27.

${ }^{166}$ Art. 26 para. 3 Directive 2009/72/EC.

${ }^{167}$ See Bundesnetzagentur (2012), p. 10. However, it should probably remain possible that customers conclude on the basis of the respective brands that the two divisions belong to the same company or group of companies.

${ }^{168}$ Bundesnetzagentur (2012), p. 10.
} 
Likewise, the business correspondence and advertising material of EUCs are to be designed so as to avoid confusion. In the case of letters, faxes, emails, price lists, etc., it should be clearly visible for the customer whether these are messages related to the public tasks fulfilled by the EUC or from private customer care. In order to avoid any risk of confusion between the two areas, EUCs must generally refrain from publishing joint customer magazines, newsletters and the like. ${ }^{169}$

Finally, it has to be ensured that customers can easily see whether the information presented on the internet is part of the private sector activity or the public sector remit of the EUC. For this reason, a joint internet presence must be avoided and separate web addresses are to be maintained for the two areas. In order to avoid any risk of confusion, different email addresses or contact forms should be used for contact requests. ${ }^{170}$ Corresponding principles must also apply to telephone communication. For the public sector and private sector activities, the EUC should have to set up separate service telephone numbers and make them known to customers. ${ }^{171}$

\subsection{Information Advantages}

For EUCs, the requirements for information unbundling according to the Swiss Electricity Supply Act are to be observed first and foremost. However, these requirements are rather general and only cover the use of information benefits from the network sector and the universal energy supply. ${ }^{172}$ Against this background, it is necessary to provide for additional measures. Where possible, these can be integrated into existing internal company guidelines, processes and systems for data compliance and data governance. ${ }^{173}$

EUCs are to be obliged to identify and document the information relevant to competition in a first step. A corresponding analysis must be carried out for all the public service areas operated by the EUCs. It must also be determined where and by means of which processes this information is to be stored physically and electronically. ${ }^{174}$ To the extent permitted by the applicable legal provisions, competitionrelevant information from the public task areas must be disclosed to all private

\footnotetext{
${ }^{169}$ See Bundesnetzagentur (2012), p. 5.

${ }^{170}$ See Bundesnetzagentur (2012), p. 6.

${ }^{171}$ See Bundesnetzagentur (2012), p. 7. For example, EKZ has different service numbers for inquiries regarding power outages and the like and for inquiries with regard to electrical installations offered by EKZ Eltop.

${ }^{172}$ See Lang (2019), p. 3.

${ }^{173}$ See VSE (2019), p. 20 et seq.

${ }^{174}$ Bundesnetzagentur (2007), p. 8.
} 
competitors on a non-discriminatory basis. ${ }^{175}$ Ideally, such publications should use an easy to find, central link on the EUC's website.

In a second step, "Chinese Walls" are to be set up between the public and private sectors. The aim of these is to ensure that the private sector does not gain information benefits from the public tasks of the utility. From an organizational point of view, a functional and spatial separation of the areas of activity is possible. At the same time, access restrictions must be provided for, if necessary, and access rights to data relevant to competition must be regulated. ${ }^{176}$

To this end, employees must be clearly assigned to the individual areas of activity. Management positions should be filled differently for the public sector and private sector activities. ${ }^{177}$ Competition-relevant information from the public task areas must only be accessible to employees who actually belong to the relevant public task area of the EUC. ${ }^{178}$ The access rights to computer systems in which competition-relevant information of the public task area is managed must be restricted accordingly for employees of the private enterprise sector. ${ }^{179}$ Consequently, employees in the private sector must not be able to access customer information (name, address, bank details, etc.) from the public sector in the integrated computer system. ${ }^{180}$

If services are provided for customers within the scope of the public remit, the EUC should not refer exclusively to its own private sector offer in this context. ${ }^{181}$ For example, it is not permitted to draw the attention of a customer for whom the utility company provides a network connection to the utility company's own range of services regarding the installation of solar systems. Employees with customer contact should be trained in how to classify customers into their respective areas of responsibility and activity and how to deal with customer enquiries regarding the private sector offer. ${ }^{182}$

\footnotetext{
${ }^{175}$ Bundesnetzagentur (2007), p. 10; Finger et al. (2009), p. 22. For example, Gebäudeversicherung Bern has undertaken to offer data records from the monopoly sector which it makes available to its subsidiaries operating in the private sector to private providers on equal terms (Competition Commission 2011b, p. 483 et seq., n. 167, Gebäudeversicherung Bern [GVB]).

${ }^{176}$ Bundesnetzagentur (2007), p. 22; see further Ziegler and Moser (2019), n. 30.

${ }^{177}$ For example, Gebäudeversicherung Bern has committed itself to this (Competition Commission 2011 b, p. 483 et seq., n. 167, Gebäudeversicherung Bern [GVB]).

${ }^{178}$ Bundesnetzagentur (2007), p. 8.

${ }^{179}$ Bundesnetzagentur (2007), p. 9.

${ }^{180}$ Bundesnetzagentur (2006), p. 24.

${ }^{181}$ Bundesnetzagentur (2007), p. 11.

${ }^{182}$ Bundesnetzagentur (2007), p. 11.
} 


\section{Summary and Outlook}

Electricity utility companies today often operate in hybrid mode. On the one hand, they carry out the public tasks assigned to them by the legislator. On the other hand, apart from the fulfillment of public tasks, they are active as entrepreneurs and thus in the private sector. Private sector activities may range from electricity products for large customers, photovoltaic and e-mobility installations to services in the field of building services engineering, internet offerings and the sale of household appliances.

A utility's private sector activities can be associated with several potential distortions of competition. It is not only cross-subsidization, which is often at the forefront of discussions, that should be considered. Rather, EUCs potentially benefit from financing advantages and, due to their legal form, from significant exceptions to taxation. Furthermore, considerable economies of scope can be achieved by hybrid EUCs, as the public and private sectors can draw on joint company resources. As a result of the proximity to the state and their function as distribution system operators, EUCs have a competitive information advantage over private suppliers (Sect. 3 above).

Guidelines for dealing with the individual distortions of competition derived from constitutional, antitrust and electricity supply law are only partially binding. In particular, there is a lack of instruments for dealing with issues related to taxation, financing and economies of scope. In contrast, the requirements relating to crosssubsidization and the exploitation of information benefits for private sector activities are more comprehensive (Sect. 4 above).

The present contribution has set out (above in Sect. 5) de lege ferenda measures to avoid distortions of competition. Irrespective of the extent to which these reform proposals are implemented, it is imperative that EUCs and their public owners seriously address the problem of distortions of competition and the measures described. Otherwise, there is a risk that their private sector activities will increasingly be rejected and that their scope for economic development will be restricted by political considerations.

\section{References}

Abegg A, Baumann P (2020) Privatwirtschaftliche Tätigkeiten von Energieversorgungsunternehmen - wie Wettbewerbsverzerrungen vermieden werden. Schriften zum Energierecht, Band 15. Dike Verlag, Zurich/St. Gallen

Abegg A, Frei M (2018) Eintritt des Staates in den Wettbewerb. Recht - Zeitschrift für juristische Weiterbildung und Praxis 3(2018):142-154

Abegg A, Seferovic G (2018) Abgeltung ungedeckter Kosten im regionalen Personenverkehr unter besonderer Berücksichtigung von Konzernstrukturen. Sui Generis 2018:360-373

Amstutz M, Carron B (2010) Kommentar zu Art. 7 KG. In: Amstutz M, Reinert M, Honsell H (eds) Basler Kommentar Kartellgesetz. Helbing Lichtenhahn, Basel 
Barney JB, Hesterly WS (2015) Strategic management and competitive advantage: concepts and cases. Pearson, Essex

Baumann P (2019) Wettbewerbsverzerrungen durch privatwirtschaftliche Staatstätigkeit. Dissertation, University of Lucerne

Baumann P (2020) Quersubventionierungen bei privatwirtschaftlicher Staatstätigkeit, Jusletter 9 March 2020. Available at https://jusletter.weblaw.ch

Beyeler F (2017) Verwirrung im (smarten) Daten-Dschungel. Bulletin SEV/VSE 12(2017):56-60

Borer J (2011) Kommentar zum Wettbewerbsrecht I, Schweizerisches Kartellgesetz. Orell Füssli, Zurich

Brennan TJ (1990) Cross-subsidization and cost misallocation by regulated monopolists. J Regul Econ 2(1):37-51

Bundesnetzagentur (2006) Gemeinsame Auslegungsgrundsätze zu den §§ 6-10 EnWG, 01 March 2006. Available at: https://www.bundesnetzagentur.de/

Bundesnetzagentur (2007) Gemeinsame Richtlinie der Regulierungsbehörden des Bundes und der Länder zur Umsetzung der informatorischen Entflechtung nach § 9 EnWG, 13 June 2007. Available at https://www.bundesnetzagentur.de

Bundesnetzagentur (2012) Gemeinsame Auslegungsgrundsätze III der Regulierungsbehörden des Bundes und der Länder zu den Anforderungen an die Markenpolitik und das Kommunikationsverhalten bei Verteilnetzbetreibern (§ 7a Abs. 6 EnWG), 16 July 2012. Available at https://www.bundesnetzagentur.de

Bürer M, de Lapparent M, Capezzali M, Carpita M (2021) Governance drivers and barriers for business model transformation. In: Hettich P, Kachi A (eds) Swiss energy governance. Springer, New York, p 219

Capobianco A, Christiansen H (2011) Competitive neutrality and state-owned enterprises: challenges and policy options. OECD Corporate Governance Working Papers No. 1. OECD Publishing, Paris

City Council Aarau (2000) Eignerstrategie des Stadtrats Aarau für die Eniwa Holding AG. Available at https://www.eniwa.ch

Competition Commission (2011a) Recht und Politik des Wettbewerbs 2011/1. Available at www. bundespublikationen.admin.ch

Competition Commission (2011b) Recht und Politik des Wettbewerbs 2011/4. Available at www. bundespublikationen.admin.ch

Competition Commission (2014) Recht und Politik des Wettbewerbs 2014/1. Available at www. bundespublikationen.admin.ch

Council Secretariat City of Bern (2006) Minutes of the City Council meeting of 11 May 2006. Available at https://ris.bern.ch

D’Arcy A, Burri S (2009) Das Rechnungswesen von Elektrizitätsversorgungsunternehmen (EVU) aus regulatorischer Sicht. In: Meyer C, Pfaff D (eds) Finanz- und Rechnungswesen - Jahrbuch 2009. WEKA, Zurich

Diebold N, Ludin M (2018) Öffentliche Beschaffungen von Strom im teilliberalisierten Stromversorgungsmarkt. Dike, Zurich/St. Gallen

Diebold NF (2014) Die öffentliche Ausschreibung als Marktzugangsinstrument. ZSR 133:219-252

Ducrey P (2009) Fallstricke für öffentliche Unternehmen im Wettbewerb. In: Hettich P (ed) Öffentliche Unternehmen zwischen Politik und Markt, Referate der Tagung vom 17. Februar 2009 in Zurich. Schriftenreihe des IRP-HSG, St. Gallen

Electricity Commission (2018) Reports on the activities of ElCom 2018. Available at https://www. elcom.admin.ch

Enz K (2018): Energiemarkt: Ostschweizer Netzbetreiber konkurrenziert private KMU. Ostschweiz am Sonntag, 7 January 2018. Available at https://www.tagblatt.ch

European Commission (2010) Interpretative Note on Directive 2009/72/EC concerning common rules for the internal market in electricity and directive 2009/73/EC concerning common rules for the internal market in natural gas, 22 January 2010. Available at https://www.ec.europa.eu 
ewl (2017) ewl kombiniert Strom und Internetprodukt, press release, 24 November 2017. Available at: https://www.ewl-luzern.ch

EY (2017) Elektrizitätswerke-Studie Schweiz 2017, Verteilnetzbetreiber der Zukunft. Ernst \& Young, Zurich

Federal Council (2004) Botschaft vom 3. Dezember 2004 zur Änderung des Elektrizitätsgesetzes und zum Stromversorgungsgesetz. Federal Gazette BB1 20041611

Federal Council (2006) Bericht vom 13. September 2006 zur Auslagerung und Steuerung von Bundesaufgaben. Federal Gazette BBl 20068233

Federal Council (2013) Botschaft vom 4. September 2013 zum ersten Massnahmenpaket der Energiestrategie 2050 und zur Volksinitiative "Für den geordneten Ausstieg aus der Atomenergie". Federal Gazette BB1 20137561

Federal Council (2017a) Botschaft vom 15. Februar 2017 zur Totalrevision des Bundesgesetzes über das öffentliche Beschaffungswesen. Federal Gazette BB1 20171851

Federal Council (2017b) Staat und Wettbewerb. Auswirkungen staatlich beherrschter Unternehmen auf die Wettbewerbsmärkte, Bericht des Bundesrates in Erfüllung der Postulate 12.4172 FDP-Liberale Fraktion vom 13.12.2012 und 15.3880 Schilliger vom 22.09.2015

Finger M, Jaag C, Lang M, Lutzenberger M, Trinker U (2009) Angemessenheit und Folgen einer funktionalen oder strukturellen Trennung von Swisscom, Studie im Auftrag von Swisscom Schlussbericht. Swiss Economics, Zurich

Flatt M, Zindel T (2017) Steuerpflicht von Schweizer Energieversorgern, Kantonal geprägte, unterschiedliche Steuerpraxen im Kontext dynamischer Entwicklungen im Schweizer Energiemarkt. EVU Partners, Aarau

Föhse K (2015) Die Leiden der jungen Strommarktordnung - aktuelle Probleme des StromVG unter besonderer Berücksichtigung der Rechtsprechung $\mathrm{zu}$ Netzgebietszuteilung und Grundversorgung. Recht - Zeitschrift für juristische Weiterbildung und Praxis 3 (2015):125-143

Föhse M (2018) Grundversorgung mit Strom - ein Überblick zu Rechtsverhältnissen und Zuständigkeiten. AJP 10(2018):1235-1250

Friederiszick HW, Röller LH, Verouden V (2008) European state aid control: an economic framework. In: Paolo B (ed) Handbook of antitrust economics. MIT Press, Cambridge

Fritsch M (2018) Marktversagen und Wirtschaftspolitik, Mikroökonomische Grundlagen staatlichen Handelns. Vahlen, Munich

Geddes RR (2004) Case studies of anticompetitive SOE behavior. In: Geddes R (ed) Competing with the government: anticompetitive behavior and public enterprises. Hoover Press, Stanford

Ghazarian L (2018) Quersubventionen und Verbundvorteile im EU-Beihilferecht unter besonderer Berïcksichtigung der beihilferechtlichen Zugangsregulierung und Infrastrukturförderung. Dissertation, University of Bonn

Graf P, Waldmeier N (2016) Wenn Geschäftsmodelle Rost ansetzen. kommunalmagazin.ch, 2:12-15

Hangartner Y (2007) Der Staat als Unternehmer. In: Rechtswissenschaftliche Abteilung der Universität St. Gallen (ed) Rechtliche Rahmenbedingungen des Wirtschaftsstandortes Schweiz, Festschrift 25 Jahre juristische Abschlüsse an der Universität St. Gallen (HSG). Dike, Zurich/St. Gallen

Hangartner Y (2012) Entscheidbesprechung zu BGer 2C_485/2010 vom 3. Juli 2012. AJP 12 (2012):1817-1823

Hänni P, Stöckli A (2013) Schweizerisches Wirtschaftsverwaltungsrecht. Stämpfli, Bern

Herrmann K (2014) Öffentliche Unternehmen, Eine ökonomische Analyse kommunaler Wirtschaftstätigkeit, List Forum für Wirtschafts- und Finanzpolitik 40:403-421

Hofmann B, Kolcava D, Thaler D (2021) The role of Switzerland in European Electricity Governance. In: Hettich P, Kachi A (eds) Swiss energy governance. Springer, New York, p 85

Jäger C, Scheidegger C (2016) Kommentar zu Art. 5 Abs. 1-4 StromVG. In: Kratz B, Merker M, Tami R, Rechsteiner S, Föhse K (eds) Kommentar zum Energierecht, Band I: WRG/EleG/ StromVG/RLG. Editions Weblaw, Bern 
Kraemer R, Stöckli A (2013) Grenzenlose Staatswirtschaft? Recht - Zeitschrift für juristische Weiterbildung und Praxis 1(2013):28-45

Krähenmann B (1987) Privatwirtschaftliche Tätigkeit des Gemeinwesens. Dissertation, University of Basel

Kratz B (2018) Speicher als Schlüsselkomponente der Energiewende. Dike, Zurich/St. Gallen

Lang L (2019) Informatorische Entflechtung als (weiterer) Treiber der Konsolidierung kleinerer EVU. EVU Partners, Aarau

Lund H, Østergaard P, Connolly D, Mathiesen BV (2017) Smart energy and smart energy systems. Energy 137:556-565

Mayoraz JF (2018) Staatliche Beihilfen in den Rechtsbeziehungen der Schweiz und der Europäischen Union, unter besonderer Berücksichtigung von ausgewählten Aspekten aus der schweizerischen Elektrizitätswirtschaft. Dissertation, University of Zurich

Müller A (2017) Die Berner breiten sich auch in Zürich aus, 1 December 2017. In: nzz.ch. Available at https://www.nzz.ch

Municipal Council Bern (2016) Neues Ausschüttungsmodell für ewb. Available at https://www. bern.ch

Municipal Council Bern (2017) Eignerstrategie Energie Wasser Bern (ewb). Available at https:// www.bern.ch

Nielsen RP (1981) Competitive advantages of state owned and controlled businesses. Manage Int Rev 21(3):56-66

OECD (2012) Competitive neutrality, Maintaining a level playing field between public and private business. OECD Publishing, Paris

OECD (2015) OECD guidelines on corporate governance of state-owned enterprises. OECD Publishing, Paris

OECD (2016) State-owned enterprises as global competitors, A challenge or an opportunity? OECD Publishing, Paris

Orelli M, Thomann M (2016) Kommentar zu Art. 10 StromVG. In: Kratz B, Merker M, Tami R, Rechsteiner S, Föhse K (eds) Kommentar zum Energierecht, Band I: WRG/EleG/StromVG/ RLG. Editions Weblaw, Bern

Peeperkorn L, Verouden V (2014) The economics of competition. In: Faull J, Nikpay A (eds) The EU law of competition. Oxford University Press, Oxford

Petrik-Haltiner TS (2017) Spannungsfelder rund um die Stromkosten und -tarife, Eine systematische Analyse der Rechtslage im Nachgang an die erste Etappe der schweizerischen Strommarktliberalisierung. Dissertation, University of Zurich

Platt D (2005) Quersubventionierung im Wettbewerbsrecht der Europäischen Union, Dissertation, University of Munich

PostCom (2013) Weisung 1/2013 der PostCom zuhanden der Schweizerischen Post betreffend den Nachweis der Einhaltung des Quersubventionierungsverbots im Einzelfall, 15 March 2013. Available at: https://www.postcom.admin.ch

Probst S, Känel L, Konersmann L (2019) Update 2019: Abrechnungslösungen für den Eigenverbrauch von Solarstrom, Eine Übersicht für Projektentwickler und Bauherren. Energie Zukunft Schweiz, Zürich

Reich J (2009) Grundsatz der Wirtschaftsfreiheit, Evolution und Dogmatik von Art. 94 Abs. 1 und 4 der Bundesverfassung der Schweizerischen Eidgenossenschaft vom 18. April 1999, Dissertation, University of Basel

Reich J (2013) Gebäudeversicherung und "negativ nachgeführte" Bundesverfassung. AJP 9 (2013):1399-1412

Rhinow R, Schmid G, Biaggini G, Uhlmann F (2011) Öffentliches Wirtschaftsrecht. Helbing Lichtenhahn, Basel

Rütsche B (2013) Was sind öffentliche Aufgaben? Recht - Zeitschrift für juristische Weiterbildung und Praxis 4(2013):153-162

Rütsche B (2016) Staatliche Leistungsaufträge und Rechtschutz. ZBJV 2(2016):71-113

Sappington DEM, Sidak GJ (2003) Competition law for state-owned enterprises. Antitrust Law J 71 (2):479-523 
Sappington DEM, Sidak GJ (2004) Anticompetitive behavior by state-owned enterprises: incentives and capabilities. In: Geddes R (ed) Competing with the government: anticompetitive behavior and public enterprises. Hoover Press, Stanford

Scheda L (2014) Kantonale Gebäudeversicherer - neue "Wettbewerber" auf dem Privatversicherungsmarkt. In: Fuhrer S (ed) Jahrbuch SGHVR 2014/Annales SDRCA 2014. Schulthess, Zurich

Schedler K, Müller R, Sonderegger RW (2016) Führung, Steuerung und Aufsicht von öffentlichen Unternehmen, Public Corporate Governance für die Praxis. Haupt, Bern

Schneider H (2016) Staat und Wirtschaft im Wettbewerb. sic! Zeitschrift für Immaterialgüter. Informations- und Wettbewerbsrecht 12:641-649

Scholl P (2015) Elektrizität. In: Biaggini G, Häner I, Saxer U, Schott M (eds) Fachhandbuch Verwaltungsrecht. Schulthess, Zurich/Basel/Geneva

Schönbächler P (1998) Wettbewerbsneutralität staatlicher Massnahmen, Dissertation, University of Zurich

Sonderegger RW (2012) Eignerstrategie als Führungsinstrument bei öffentlichen Energieversorgern, Gründe und Wege für die Einführung. Bulletin SEV/VSE 2012(7):14-16

Sonderegger RW (2014) Führung, Steuerung und Aufsicht von öffentlichen Unternehmen in Schweizer Städten, Erkenntnisse der Studie zum Stand der Umsetzung von Public Corporate Governance in Städten und grösseren Gemeinden der Schweiz. IMP-HSG, St. Gallen

Spiekermann MK (2010) Vermeidung von Quersubventionen durch sektorspezifische Regulierung am Beispiel der deutschen Elektrizitätswirtschaft. Dissertation, University of Bonn

Stadtwerk Winterthur (2013) Eignerstrategie für Stadtwerk Winterthur. Available at https://www. stadtwerk.winterthur.ch

State Council Basel-Stadt (2018) Eignerstrategie für die IWB Industrielle Werke Basel 2019-2022. Available at https://www.bs.ch

State Council Basel-Stadt (2019) Ratschlag Gesamtkonzept Elektromobilität. Available at https:// www.bs.ch

Stäuble L, Schraner F (2018a) Kommentar zu Art. 4 Abs. 2 KG. In: Zäch R, Arnet R, Baldi M, Kiener R, Schaller O, Schraner F, Spühler A (eds) DIKE Kommentar zum Bundesgesetz über Kartelle und andere Wettbewerbsbeschränkungen. Dike, Zurich/St. Gallen

Stäuble L, Schraner F (2018b) Kommentar zu Art. 7 KG. In: Zäch R, Arnet R, Baldi M, Kiener R, Schaller O, Schraner F, Spühler A (eds) DIKE Kommentar zum Bundesgesetz über Kartelle und andere Wettbewerbsbeschränkungen. Dike, Zurich/St. Gallen

Stillfried M (2010) Die energierechtliche Jahresrechnung gemäss Stromversorgungsgesetz, Offene Fragen und Lösungsvorschläge. Der Schweizer Treuhänder 84(4):180-187

Stöckli A (2016) Messwesen im Bereich der elektrischen Energie - geschlossener oder offener Markt? In: Die Schweizerische Vereinigung für Verwaltungsorganisationsrecht SVVOR (ed) Verwaltungsorganisationsrecht -Staatshaftungsrecht - öffentliches Dienstrecht, Jahrbuch 2015. Stämpfli, Bern

Stoffel WA, Graber N (2013) L'assurance incendie et le droit de la concurrence. In: Rumo-Jungo A, Pichonnaz P, Hürlimann-Kaup B, Fountoulakis C (eds) Une empreinte sur le Code civil. Stämpfli, Bern

Stoffel WA, Murith S (2019) Entreprises publiques et droit de la concurrence. In: Hochreutner I, Stoffel WA, Amstutz M (eds) 10ème Journée de droit de la concurrence/10. Tagung zum Wettbewerbsrecht. Growth Publisher Law, Bern

Swiss Federal Office of Energy (2018a) Faktenblatt 2 - Der Schweizer Strommarkt. Available at https://www.newsd.admin.ch

Swiss Federal Office of Energy (2018b) Markt- und Wettbewerbsanalyse Grundlagenpapier für den erläuternden Bericht zur Vernehmlassungsvorlage Revision StromVG vom Oktober 2018. Available at https://www.bfe.admin.ch

Swiss Federal Office of Energy (2018c) Revision des Stromversorgungsgesetzes (volle Strommarktöffnung, Speicherreserve und Modernisierung der Netzregulierung), Erläuternder Bericht zur Vernehmlassungsvorlage, October 2018. Available at https://www.admin.ch

Tschannen P, Zimmerli U, Müller M (2014) Allgemeines Verwaltungsrecht. Stämpfli, Bern 
Uhlmann F (1997) Gewinnorientiertes Staatshandeln, Möglichkeiten und Zulässigkeit gewinnorientierter staatlicher Eigenbetätigung aus wirtschaftsverfassungsrechtlicher Sicht. Dissertation, University of Basel

Vaterlaus S, Zenhäusern P, Kaufmann C, Worm H (2017) Staat und Wettbewerb, Institutionelle und wettbewerbliche Aspekte bei kantonalen und kommunalen Unternehmen, Studie im Auftrag des Staatssekretariats für Wirtschaft SECO. Polynomics, Olten

Vettori A, Wunderlich A, Iten R, Bulgheroni R, Streit D, Camacho-Bütikofer M, Brandes C (2018) Benchmarking von Energieversorgungsunternehmen in den Bereichen Energieeffizienz und erneuerbare Energien, Resultate der Erhebungsrunde 2017/18. Energieschweiz, Bern

Vogel S (2000) Der Staat als Marktteilnehmer, Voraussetzungen der Zulässigkeit wirtschaftlicher Tätigkeit des Gemeinwesens in Konkurrenz zu Privaten. Dissertation, University of Zurich

Vonplon D (2019) Stromkonzern zapft Kundendatei ab. Neue Zürcher Zeitung, 28 June 2019. Available at https://www.nzz.ch

VSE (2018) Kostenrechnungsschema für Verteilnetzbetreiber der Schweiz, Branchensystematik für die Kostenermittlung im Zusammenhang mit der Netznutzung. VSE/AES, Aarau

VSE (2019) Data Policy in der Energiebranche, Rahmenwerk für den gesamtheitlichen Umgang mit Daten in der Energiebranche. VSE/AES, Aarau

Waldmeier D (2018) Insolvenz verselbständigter Verwaltungseinheiten von Bund und Kantonen, Unter besonderer Berücksichtigung staatlicher Einstandspflichten. Dissertation, University of St. Gallen

Weber RH (1986) Wirtschaftsregulierung in wettbewerbspolitischen Ausnahmebereichen, Studien zur staatlichen Wirtschaftsregulierung und zum Einsatz der Regulierungsinstrumente in den Transport-, Kommunikations- und Energiemärkten in der Schweiz und in den Vereinigten Staaten von Amerika, Habilitation University of Zurich. Nomos, Baden-Baden

Weber RH, Volz S (2013) Fachhandbuch Wettbewerbsrecht, Expertenwissen für die Praxis. Schulthess, Zurich

Zäch R (2005) Schweizerisches Kartellrecht. Stämpfli, Bern

Ziegler AR, Moser P (2019) Sind die kantonalen Gebäudeversicherungsmonopole “eurokompatibel"? Jusletter 12 August 2019. Available at https://jusletter.weblaw.ch

Andreas Abegg is Head of the Centre for Public Commercial Law at Zurich University of Applied Sciences, Winterthur, Switzerland.

Phil Baumann is Senior Academic Assistant at the University of Lucerne Faculty of Law, Lucerne, Switzerland.

Open Access This chapter is licensed under the terms of the Creative Commons Attribution 4.0 International License (http://creativecommons.org/licenses/by/4.0/), which permits use, sharing, adaptation, distribution and reproduction in any medium or format, as long as you give appropriate credit to the original author(s) and the source, provide a link to the Creative Commons license and indicate if changes were made.

The images or other third party material in this chapter are included in the chapter's Creative Commons license, unless indicated otherwise in a credit line to the material. If material is not included in the chapter's Creative Commons license and your intended use is not permitted by statutory regulation or exceeds the permitted use, you will need to obtain permission directly from the copyright holder.

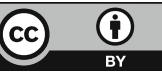

